\title{
Groundwater assessment of Halabja Saidsadiq Basin, Kurdistan region, NE of Iraq using vulnerability mapping
}

\author{
Twana O. Abdullah ${ }^{1,2} \cdot$ Salahalddin S. Ali ${ }^{3} \cdot$ Nadhir A. Al-Ansari ${ }^{4}$
}

Received: 25 March 2015 / Accepted: 1 December 2015 /Published online: 16 March 2016

(C) The Author(s) 2016. This article is published with open access at Springerlink.com

\begin{abstract}
Halabja Saidsadiq Basin is located in the northeastern part of Iraq covering an area of about $1278 \mathrm{~km}^{2}$ with a population of about 190,727 . Groundwater is the principal source of water in this area. Agricultural practices within the basin are widespread and located close to groundwater wells. This poses imminent threat to these resources. DRASTIC model integrated with GIS tool has been used to evaluate the groundwater vulnerability of this area. In addition, the DRASTIC model was modified using nitrate concentrations and sensitivity analysis to modify the recommended weighting value to get accurate results. The modified rates were calculated using the relations between each parameter and the nitrate concentration in the groundwater based on the Wilcoxon rank-sum non-parametric statistical test. While, to calibrate all types of modifications, the Pearson's correlation coefficient was applied. The standard vulnerability map of the studied basin classified the basin into four zones of
\end{abstract}

Nadhir A. Al-Ansari

nadhir.alansari@1tu.se; Sven.Knutsson@1tu.se

Twana O. Abdullah

Twana.abdullah@univsul.edu.iq

Salahalddin S. Ali

salahalddin.ali@univsul.edu.iq

1 Department of Geology, University of Sulaimani, Sulaimani, Kurdistan region, Iraq

2 Department of Civil, Environmental and Natural Resources and Engineering, Division of Mining and Geotechnical Engineering, Lulea University of Technology, Lulea, Sweden

3 University of Sulaimani, Sulaimani, Kurdistan region, Iraq

4 Department of Civil, Environmental and Natural Resources and Engineering, Lulea University of Technology, Lulea, Sweden vulnerability index including very low (34\%), low(13\%), moderate (48 \%), and high (5\%) vulnerability index, while the combined modification classified the area into five classes: very low $(7 \%)$, low (35\%), moderate (19\%), high (35\%), and very high (4\%). The results demonstrate that both modified DRASTIC rate and weight were dramatically superior to the standard model; therefore, the most appropriate method to apply is the combination of modified rate-weight.

Keywords Vulnerability · Nitrate concentration · Sensitivity analysis · Modified DRASTIC $\cdot$ Halabja Saidsadiq Basin

\section{Introduction}

Many regions in the world are explicitly dependent on groundwater as one of the main water resources, specifically in arid and semi-arid regions. In Halabja and Saidsadiq area which is located in the northeastern part of Iraq (see Fig. 1), groundwater plays an important role in providing water for drinking and industrial and agricultural activities (GWDS 2014). This area in the past was destroyed by army attacks by chemical weapons. In addition, some parts of the area are characterized by the lack of water projects. After 2003, the area is experiencing considerable economic development and enhanced security. Furthermore, the administrative structure of Halabja has been changed from district to governorate in March 2014; this will definitely enhance the beginning of greater economic development and advancement. In view of these changes, there is an increase in the numbers of people heading to live in this basin and its surrounding regions. This is imposing a growing demand for water which has placed substantial pressures on water resources. It should be mentioned, however, that the area has a large number of surface 
Fig. 1 Location map of study basin

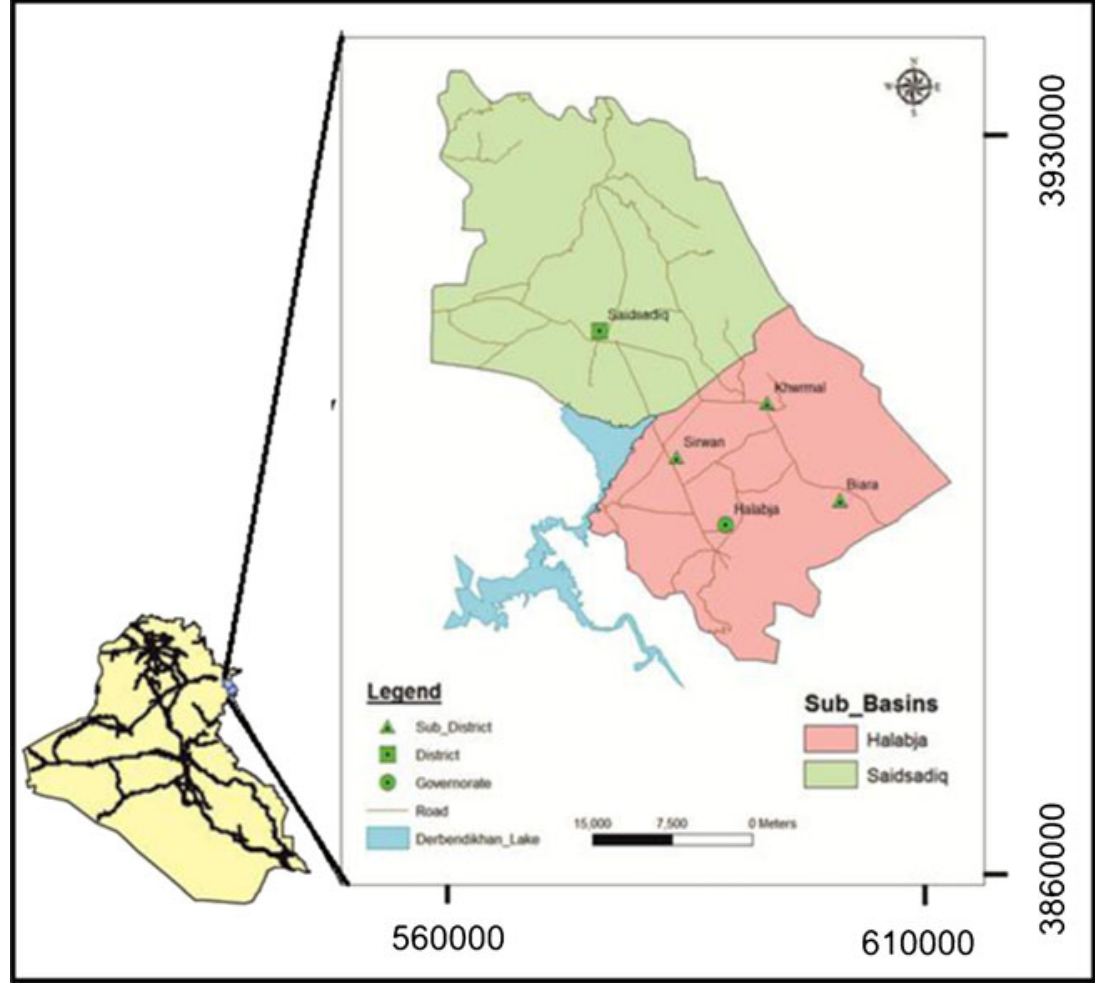

water projects which are also heavily dependent on groundwater for drinking, irrigation, and industry.

According to data obtained from the Directorate of Groundwater in Sulaimani City, several thousand deep wells exist in the studied area. As a consequence, the study of the groundwater resources and its potential pollution in the area becomes a necessity. Moreover, it is worth noting that no previous studies have been conducted on this vital area in terms of contamination.

The most suitable, effective, and widely used model to assess groundwater vulnerability to a wide range of potential contaminants is DRASTIC which has been developed by the Environmental Protection Agency (EPA) of the USA to recognize the pollution potential of aquifers (Aller et al. 1987, Fritch et al. 2000; Piscopo 2001; Neshat et al. 2013; Abdullah et al. 2015b).

In any specified area, vulnerability to contamination identifies a dimensionless index function of hydrogeological factors, anthropogenic influences, and sources of contamination (Plymale and Angle 2002). The DRASTIC index comprises seven parameters with different rating and weighting value and is calculated based on the following equation (Aller et al. 1987):

$V=\sum_{i=1}^{7}(W i \times R i)$

where

$V=$ index value, $W_{i}=$ weighting coefficient for parameter $i$, and $R_{i}=$ related rating value.
DRASTIC method as designed by Aller et al. (1987) consists of seven physical parameters. The most important mappable factor that controls groundwater pollution comprises to be the depth to water (D), net recharge (R), aquifer media (A), soil media (S), topography (T), impact of vadose zone media (I), and hydraulic conductivity (C). These parameters are weighted from one to five based on their relative significance in contributing to the contamination potential. All rating and weighting value are explained in Table 1 based on Aller et al. (1987). The achieving index is a qualified measure of vulnerability to contamination; areas with a higher index value are more vulnerable than those with a lower index (Table 1), standard DRASTIC weight and rate after Aller et al. (1987).

Javadi et al. (2011) mentioned that in spite of its attractiveness, the DRASTIC method does have some inconvenience including the effect of regional characteristics which are not accounted and the same rating and weight values have been used everywhere. In addition, there is no regular algorithm to examine and confirm the method for an aquifer. Therefore, as recommended by Kalinski et al. (1994) and some other researchers, it is important to correlate the vulnerability index with chemical or contaminant parameters based on the specific situation in terms of man-made chemical activities.

In order to modify and correlate the precision of the vulnerability method and its applicability to the current study area, two methods counting nitrate as a chemical contaminant indicator and effective sensitivity weight have been selected. Normally, nitrate is not present in groundwater under natural conditions, so if it is present, it may indicate the movement of 


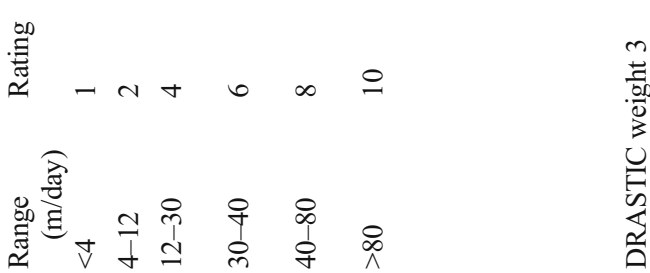
气 $\circ a \infty \sim 6 n+\operatorname{tr}$
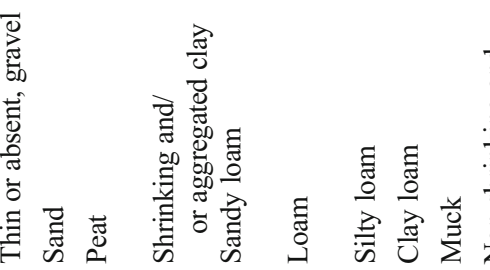

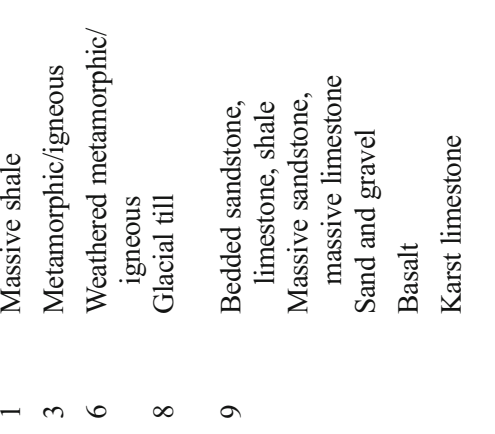

a contaminant from the surface to the ground until reaching the groundwater (Javadi et al. 2011), especially in the land dedicated to agricultural use. Consequently, this paper distinguished a first attempt for groundwater vulnerability mapping in this basin and the first attempt for modifying DRASTIC method in Kurdistan region. Therefore, modifying the DRASTIC method as a means of vulnerability assessment using nitrate concentration and sensitivity method is the main objective of this paper. Definitely, the DRASTIC computation is controlled by both associated rates and weights value so calibration of these parameters becomes a necessity. This study will, therefore, focus on calibrating both parameters to achieve a higher degree of accuracy.

\section{Study area}

Geographically, Halabja Saidsadiq Basin is located in the northeastern part of Iraq between the latitude $35^{\prime \prime} 00^{\prime} 00^{\prime \prime}$ and $35^{\prime \prime} 36^{\prime} 00^{\prime \prime} \mathrm{N}$ and the longitude 45" 36' $00^{\prime \prime}$ and 46" $12^{\prime}$ 00" E (Fig. 1). Ali (2007) divided this basin into two subbasins by including Halabja-Khurmal and Saidsadiq sub-basins. The whole area of both sub-basins is about $1278 \mathrm{~km}^{2}$ with population of about 190,727 in early 2015 according to the data achieved from Statistical Directorate in Sulaimaniyah. It is characterized by a distinct continental interior climate with hot summers and cold winters of the Mediterranean type with the average annual precipitation ranging from 500 to $700 \mathrm{~mm}$. About $57 \%$ of the studied area is an arable area due to its suitability for agriculture. Consequently, the uses of fertilizers and pesticides are common practices, so it affects the groundwater quality (Huang et al. 2012). Normally, different types of inorganic chemical fertilizer were used in the studied area, namely sodium nitrates and chemical compounds that contain nitrogen in amide form (Statistical Directorate in Sulaimaniyah 2014). In addition, all of the municipal wastewater from the cities of Halabja and Saidsadiq and all other sub-district sites within this basin infiltrate into the groundwater every year.

\section{Geology of the study basin}

Geologically, the studied area is located within western Zagros fold-thrust belt, structurally located within the High Folded, Imbricated, and Thrust Zones (Buday 1980; Buday and Jassim 1987; and Jassim and Guff 2006). The age of the exposed rocks in the area is from Jurassic to recent (Figs. 2 and 3). The oldest exposed rocks in the basin are Sarki and Sehkanian Formations of Jurassic age (Bellen et al. 1959). These are followed by lower and middle Jurassic rocks including Barsarin (limestone and dolomitic limestone), Naokelekan (bituminous limestone), and Sargalu (Ali 2007) Formations. The Qulqula Group 
Fig. 2 Geological map of study basin

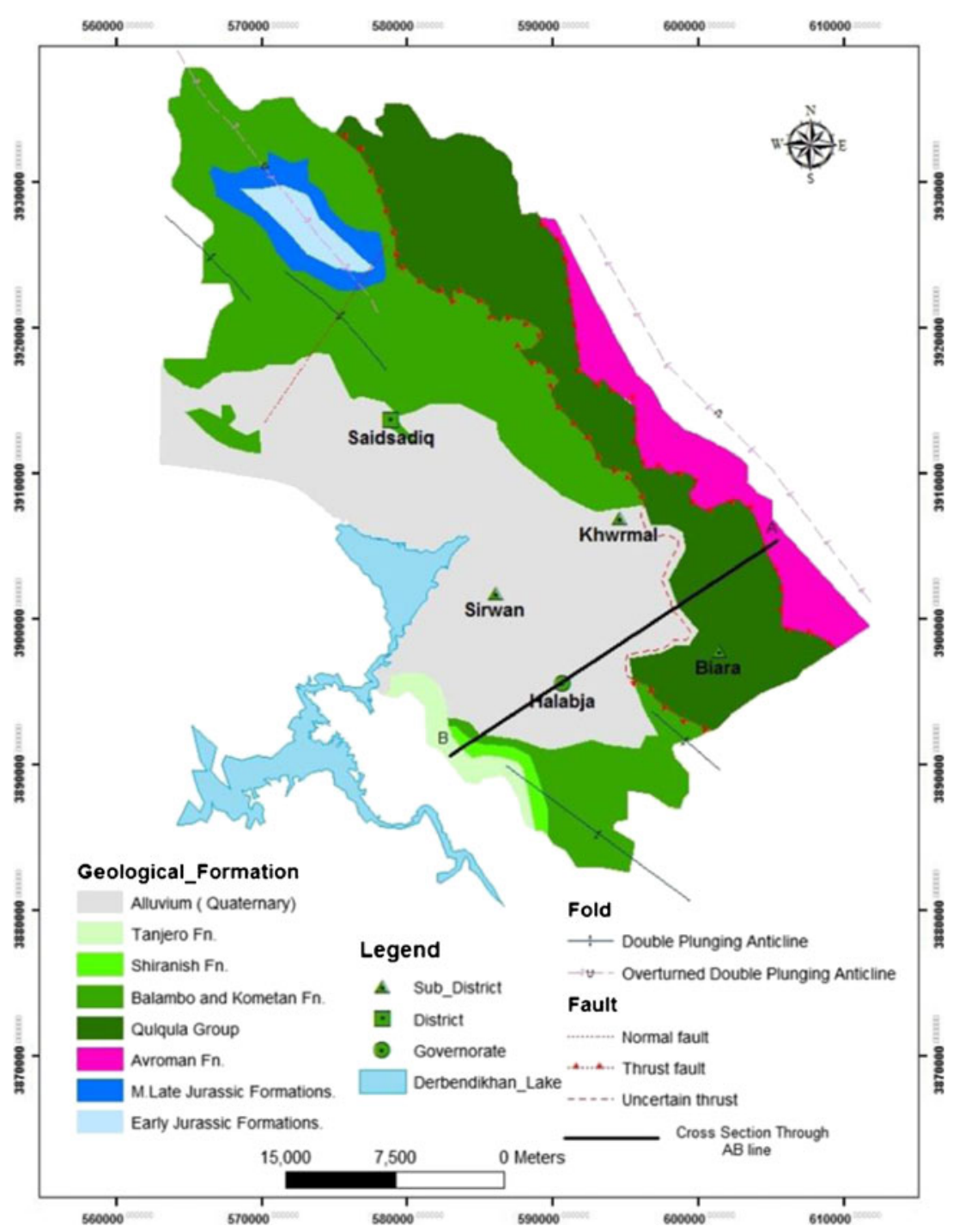

consists of two formations, the Qulqula Radiolarian Formation and the Qulqula Conglomerate Formation. The exposures of the Upper Cretaceous Kometan (Turonian) and Lower Cretaceous Balambo (ValanginianCenomanian) Formations are widespread in the area where they are exposed in both sub-basins. Shiranish Formation (Campanian) and Tanjero Formation are also exposed in the basin but with restricted outcrops.

Quaternary (Alluvial) deposits are the most important unit in the area in terms of hydrogeological characteristic and water supply. These sediments are deposited as debris flow on the gently sloping plains, as channel deposits, as channel margin deposits, and as overbank deposits (Ali 2007). Previous studies (e.g., Ali 2007; Baziany 2006; Baziany and Karim 2007) stated that the thickness of recent deposits is up to $150 \mathrm{~m}$ thick while field observations in this study had recorded thicknesses of these deposits up to nearly $300 \mathrm{~m}$.

\section{Hydrogeology and hydrology of the study basin}

Permeability and porosity are the main principal factors in determining the potential of the area to be considered as a water-bearing aquifer. The area is characterized by at least four different hydrogeological aquifers due to the presence of different geological units. The characteristic features of the aquifers are tabulated in Table 2. The collected in the field and those listed in the archives of the groundwater department at Sulaimani show that the mountain series, which surround the basin in the northeast and southeast, are characterized by high depth of groundwater. Toward the center and the southeastern part, the groundwater level has a relatively lower depth. The movement of groundwater is usually from high elevated areas at the north and northeast and south and southeast toward southwest or generally toward the reservoir of Derbandikhan Dam (Fig. 4). 
Fig. 3 Cross section through line $A-B$ (FAO 2001 and Ali 2007)

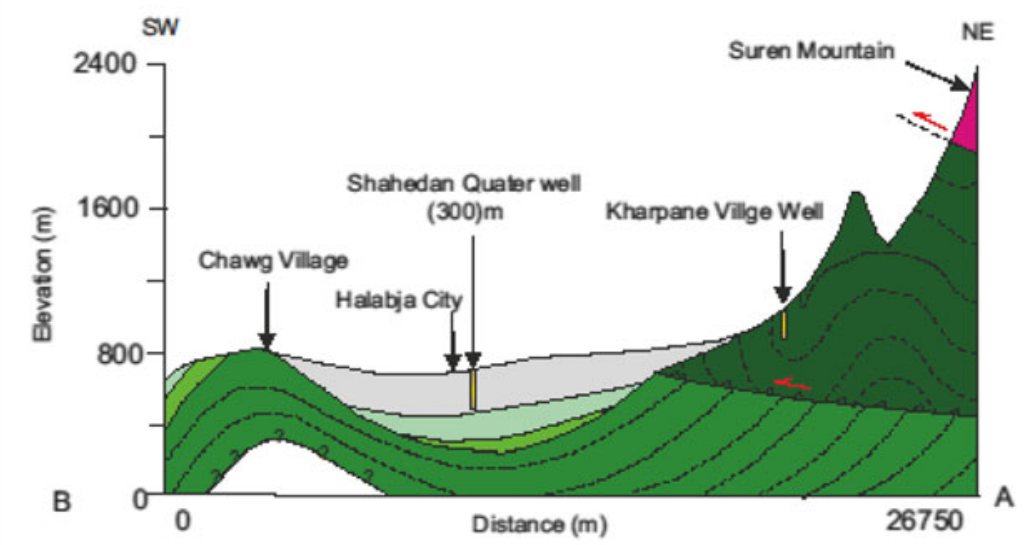

Legend
VScale: $1.5 \mathrm{~cm}=400 \mathrm{~m}$

H.Scale: $1.5 \mathrm{~cm}=1611.4 \mathrm{~m}$
Furthermore, several rivers exist in the area, such as Sirwan, Zalm, Chaqan, Biara, Reshen, and Zmkan. All these rivers impound their water in Derbandikhan reservoir. There are several springs within the basin (see Fig. 4). These springs can be classified into three classes according to their water discharge. The first group has a discharge that is less than $10 \mathrm{~L} / \mathrm{S}$ (such as Anab, Basak, Bawakochak, and 30 other springs). The second group has a discharge of 10 to $100 \mathrm{~L} / \mathrm{S}$ (such as Sheramar, Qwmash, Khwrmal, and Kani Saraw), and finally, those having a water discharge more than $100 \mathrm{~L} / \mathrm{S}$ (such as Garaw, Ganjan, Reshen, Sarawy Swbhan Agha, and three other springs)(Fig. 4).

Table 2 Type of aquifers in the study basin

\begin{tabular}{|c|c|c|c|}
\hline Aquifer type & $\begin{array}{l}\text { Geological } \\
\text { formation }\end{array}$ & Thickness (m) & References \\
\hline $\begin{array}{l}\text { Intergranular } \\
\text { aquifer }\end{array}$ & $\begin{array}{r}\text { Quaternary } \\
\text { deposits }\end{array}$ & More than 300 & Authors \\
\hline Fissured aquifer & $\begin{array}{l}\text { Balambo } \\
\text { Kometan }\end{array}$ & 250 & Ali 2007 \\
\hline $\begin{array}{l}\text { Fissured-karstic } \\
\text { Aquifer }\end{array}$ & $\begin{array}{l}\text { Avroman } \\
\text { Jurassic } \\
\quad \text { formation }\end{array}$ & $\begin{array}{l}200 \\
\text { From } 80 \text { to } 200\end{array}$ & $\begin{array}{l}\text { Jassim and } \\
\text { Goff } 2006\end{array}$ \\
\hline $\begin{array}{l}\text { Non-aquifer } \\
\text { (Aquitard) }\end{array}$ & $\begin{array}{l}\text { Qulqula } \\
\text { Shiranish } \\
\text { Tanjero }\end{array}$ & $\begin{array}{l}\text { More than } 500 \\
225 \\
2000\end{array}$ & $\begin{array}{l}\text { Jassim and } \\
\text { Goff } 2006\end{array}$ \\
\hline
\end{tabular}

\section{Methodology}

\section{Material and source of data}

The data used and their source for groundwater vulnerability mapping are presented in Table 3 and the processes explained in Fig. 5. Features were used to create the shape files with ArcMap 10 software, including the geological, hydrogeological, soil map, and hydrochemical data for the study area. The topographic map of the area was digitized and converted from a slope map into shape files. Depth to water levels was measured from several wells in the field using an electrical sounder in addition to previous records of drilled and tested wells. The thickness of the saturated zone was determined from drilled wells directly supervised by researchers for this study during field work. In addition, relevant data were added which were obtained from the Groundwater Directorate in Sulaimani and other private companies. Pumping test results of the wells within the area were used to calculate the hydraulic conductivity. "AQTESOLV" software was used in these calculations. Water samples from 39 wells from different groundwater aquifers in Halabja Saidsadiq Basin were collected in 1-L polyethylene bottles and analyzed for nitrate concentration. These samples were stored in the refrigerator until analysis to prevent deterioration and changes in water quality. The samples were analyzed by the Laboratory of the Department of Environmental Directorate of Sulaimani. 
Fig. 4 Hydrogeological map of study basin

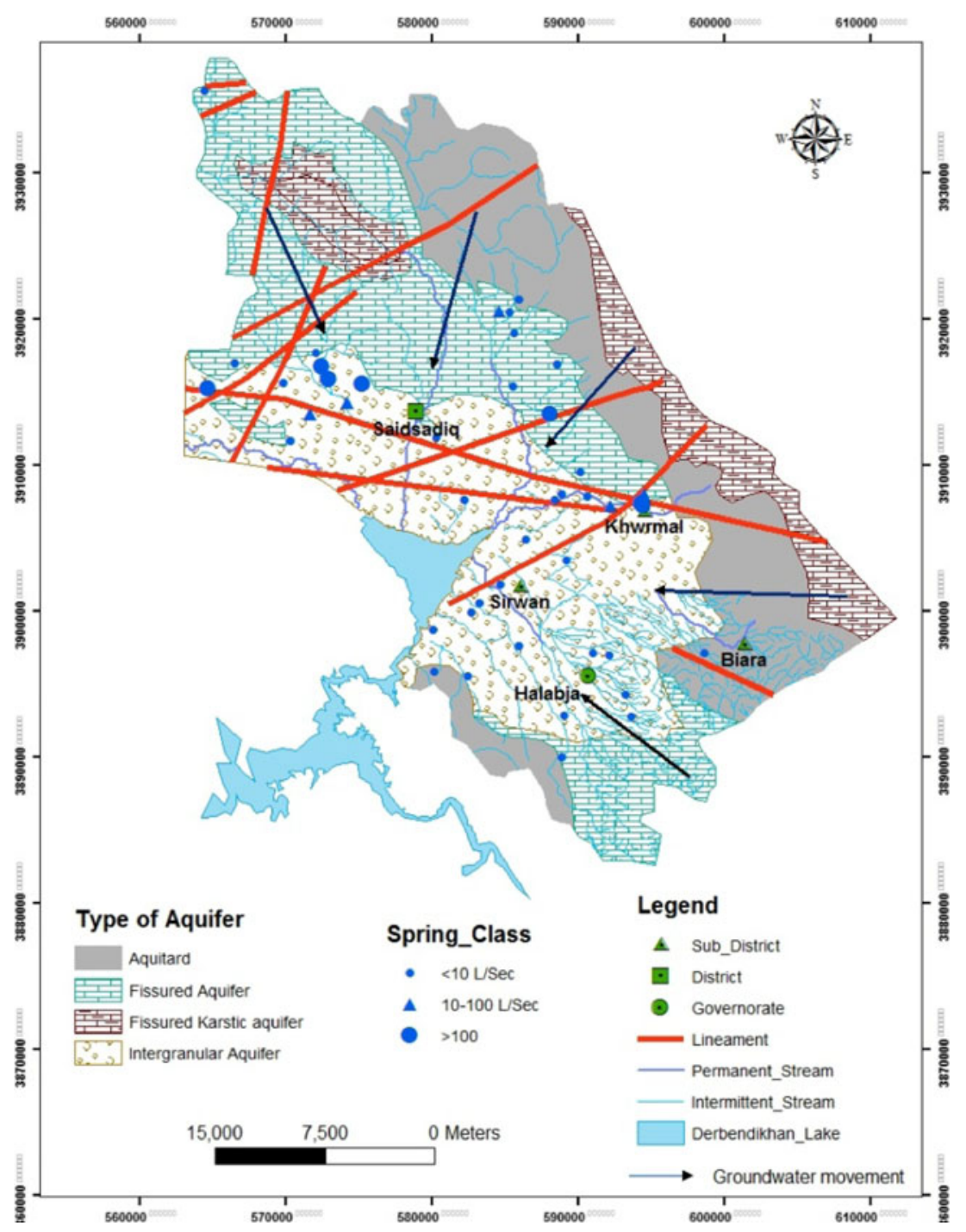

\section{Standard DRASTIC model}

DRASTIC model applied in a GIS environment has been used to evaluate the vulnerability of the study area. This model is recommended by the US committee of Environmental Protection Agency (Aller et al. 1987). Seven parameters are used in the model (see Table 2) to represent the concept of the hydrogeological setting that includes the major geologic and hydrologic factors affecting and controlling the groundwater movement into, through, and out of an area (Aller et al. 1987). Each parameter has a specific rate and weight value in order to evaluate the intrinsic vulnerability index. In addition, Aller et al. (1987) defined the seven parameters by the short form "DRASTIC" which is used to mapping groundwater vulnerability (Tables 1 and 2). Each parameter has a rating on a scale of 1 to 10 , based on functional curves. This rating is then
Table 3 Source of data for DRASTIC model

\begin{tabular}{ll}
\hline Data type & Sources \\
\hline Depth to water table & Archives of Groundwater Directorate in Sulaimani with data from field \\
Net recharge & Halabja Meteorological Station and water balance method \\
Aquifer media & Archives of Groundwater Directorate in Sulaimani and geological map \\
Soil media & Soil map by FAO 2001 and Berding 2003. \\
Topographic map & DEM with 30 m pixel size \\
Impact of vadose zone & Archives of Groundwater Directorate in Sulaimani \\
Hydraulic conductivity & Archives of Groundwater Directorate in Sulaimani with data from field \\
\hline
\end{tabular}




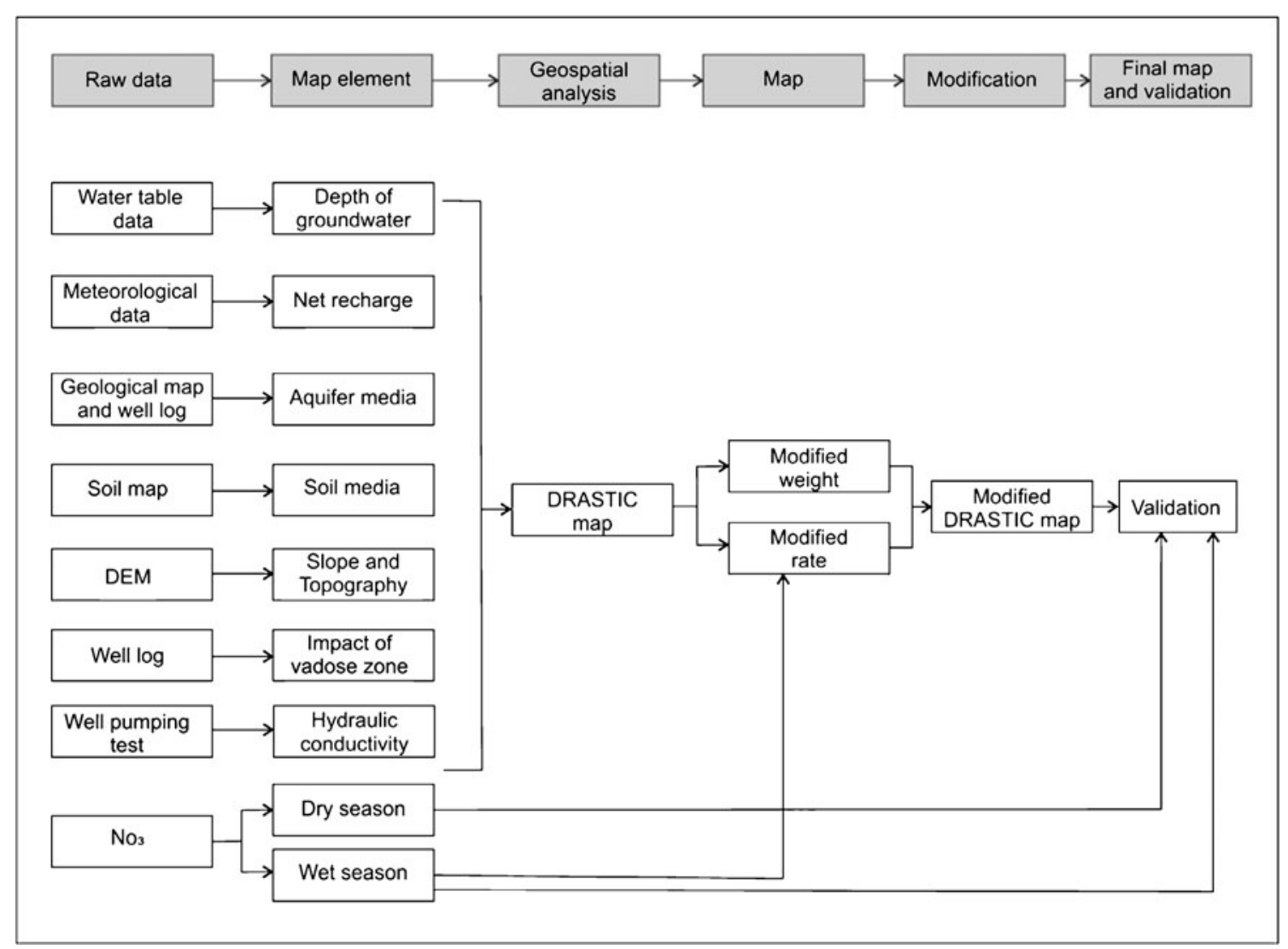

Fig. 5 Methodology processes applied in this study

scaled by a weighting factor from 1 to 5 , according to their relative susceptibility to pollutants. The standard DRASTIC index $\left(\mathrm{DI}_{(w-r)}\right)$ calculated is based on the linear combination of all parameters as demonstrated by the following equation:

$\mathrm{DI}=D W D_{r}+R W R_{r}+A W A_{r}+S W S_{r}+T W T_{r}+I W I_{r}+C W C_{r}$

where

DI is the DRASTIC index; $D, R, A, S, T, I$, and $C$ are the seven parameters; $w$ is the weight parameter, and $r$ is the rate of the parameter. All the recommended rates and weight are scheduled in Table 1.

$D$ is the depth to groundwater which is described as the distance of the unsaturated zone that pollutant desires to travel through to reach the water table. For this paper, groundwater levels were measured and documented in about 1200 wells. Water table measurements were taken in May and in early June because these months are considered as the potential worst-case scenario due to the low depth of groundwater. The inverse distance weighted (IDW) were used to interpolate the data to construct the depth to water table layer as a raster format and then reclassified based on the ranges and rating recommended by Aller et al. (1987). In Halabja Saidsadiq basin, the depth to groundwater varies from zero to more than $100 \mathrm{~m}$. Therefore, nine classes were used for the studied basin.
These are $0-1.5,1.5-4.5,4.5-7.5,7.5-10,10-12.5,12.5-15$, 15-23, 23-30, and more than $30 \mathrm{~m}$.

$R$ is the net recharge which defines the amount of water that penetrates into the ground and move through the unsaturated zone to reach the water table. The net recharge was estimated from the meteorological data for the period starting from 2001 to 2002 to 2013-2014 based on the following equation which was recommended by Mehta et al. (2006):

$\mathrm{NR}=P-\mathrm{ET}-R_{0}$

where NR is the net recharge in millimeters per year, $P$ is the annual precipitation in millimeter, ET is the calculated evapotranspiration in millimeters per year, $R_{0}$ is the total runoff in millimeters. $P$ was calculated from the average total yearly precipitation which is about $691.16 \mathrm{~mm} /$ year. While ET were calculated based on crop water balance method by FAO Penman Monteith method using CROPWat8.0 software (Allen et al. 2006). $R_{0}$ was calculated based on the Soil Conservation Service (SCS) method to estimate the total runoff for the basin. The basin was divided into several curve numbers $(\mathrm{CN})$ that were recommended by Ali (2007) and then using the following equation:

$$
\begin{aligned}
& Q=(P-0.2 S)^{2} /(P+0.8 S) \text { for } P>0.2 S \\
& S=(25400 / C N)-254
\end{aligned}
$$


where $Q=$ accumulated runoff excess $(\mathrm{mm}) . P=$ accumulated average monthly rainfall $(\mathrm{mm}) . S_{0}$, the annual runoff of this basin is about $169 \mathrm{~mm}$ and the annual net recharge for the whole basin is equal to $172.54 \mathrm{~mm}$. Finally, the net recharge map of the basin constructed was based on the net recharge percent distribution over the basin and then the resulting map was converted from polygon to raster format in GIS environment.

Aquifer media (A) and the impact of the vadose zone were constructed based on the geological map of the basin and from the drilling well logs. Four sections of the aquifer media were classified in the studied basin. The rated values for each media based on Aller et al. (1987 and 1985) were illustrated as 9, 6, 5 , and 3. While, three segments of the vadose zone were comprised with organized rating values of 4,5 , and $8 . S$ is the soil media (texture and type) which defines the ability of a pollutant to move vertically into the vadose zone (Lee 2003). Three different soil media were found in the area based on the soil map proposed by FAO (2001) and Berding (2003) including silty loam, shrinking, and/or aggregated clay and thin or absent with ratings of 4,7 , and 10 , respectively.

$T$ map refers to the topographic map that describes the slope of the surface area. The pollutants are remaining for a long period over an area with a low percent of slope value and vice versa (Hernandez et al. 2004). This map was constructed from the digital elevation model (DEM) with a pixel size of $30 \mathrm{~m}$, and the slope aspect was then calculated from it in ArcGIS 10. The topography of the area was classified into five classes ranging as $0-2,2-6,6-12,12-18$, and more than $18 \%$. Hydraulic conductivity $(C)$ describes the ability of the aquifer material to transmit water through it, and contaminant migration is controlled by the permeability of the media (Hamamin 2011). The hydraulic conductivity map was constructed by employing the pumping test result of about 10 wells. The pumping test data were analyzed using AQTESOL 4.0 software to determine the transmissivity of the aquifer, and then, Eq. (6) was used to calculate the hydraulic conductivity:

$C=T / b$

where $C$ is the hydraulic conductivity ( $\mathrm{m} /$ day), $T$ is the transmissivity $\left(\mathrm{m}^{2} /\right.$ day), and $b$ is the aquifer saturated thickness (m). The area with high hydraulic conductivity revealed a higher chance of distributing pollutants. Two classes of conductivity rating were achieved. After generating all the required layers, each pixel was classified and rated then multiplied by their respective weighting factor and the DRASTIC index was determined. The final index obtained was divided into several groups as proposed by Aller et al. (1987). A small value designated low vulnerability potential while a large value represents areas that have high vulnerability potential.

\section{Modification of the DRASTIC model}

\section{Using nitrate concentration}

Due to fact that the study area is characterized by an active agricultural exertion, nitrate concentration was used to modify the standard DRASTIC method for the studied basin. Sampling and analysis for nitrate concentration were carried out for 39 groundwater samples in two different seasons, the samples were collected and analyzed at the end of September 2014 for dry season and end of May 2015 for wet season. The May 2015 samples were used to modify the model, while the variation in nitrate concentration from dry to wet season was used to validate the model. Figure 6 illustrates the location of the sampled wells where GPS technique was used to get the precise location of each well.

Normally, nitrate infiltrates from the surface toward the groundwater, so it was used as the primary control parameter for contamination. The genuine condition of the area can be established for the vulnerability index by using nitrate as an indicator. Panagopoulos et al. (2006) and Neshat et al. (2014) proposed that the rates and weights can be optimized but the following conditions should be satisfied: the agricultural activities should be the only source of nitrate concentration on the surface, and nitrate reaching to the groundwater should be due to recharges from the surface over a long period.

In this method, the rates of five maps of DRASTIC method were modified according to the mean nitrate concentration including depth to water table, net recharge, soil media, impact of vadose zone, and hydraulic conductivity, while both aquifer media and topography were kept the same. The Wilcoxon rank-sum non-parametric statistical test (Neshat et al. 2013) was used to compute the modified rate of each parameter in the DRASTIC method. The highest and lowest rates were allocated to the highest and lowest mean nitrate concentrations, respectively, and the residual rates were modified linearly (Wilcoxon 1945 cited in Neshat et al. 2013). In addition, if there is no data for mean concentration of nitrate in each class, the standard rate of the DRASTIC method was used. The new maps were designed using the new modified rating system for each parameter in the DRASTIC model.

\section{Using sensitivity analysis}

As illustrated by Babiker et al. (2005), the weights used to calculate the vulnerability index might be changed based on the different geological and hydrogeological conditions of the study area. Sensitivity analysis evaluates the effective weights of each parameter and compares it with their original weights. The effective weight is the function of the value of a single parameter as well as the weight assigned to it by the DRASTIC model (Babiker et al. 2005). The impact of each parameter in the index computation was assessed by achieving 
Fig. 6 Nitrate sampling sites and class concentration at study basin

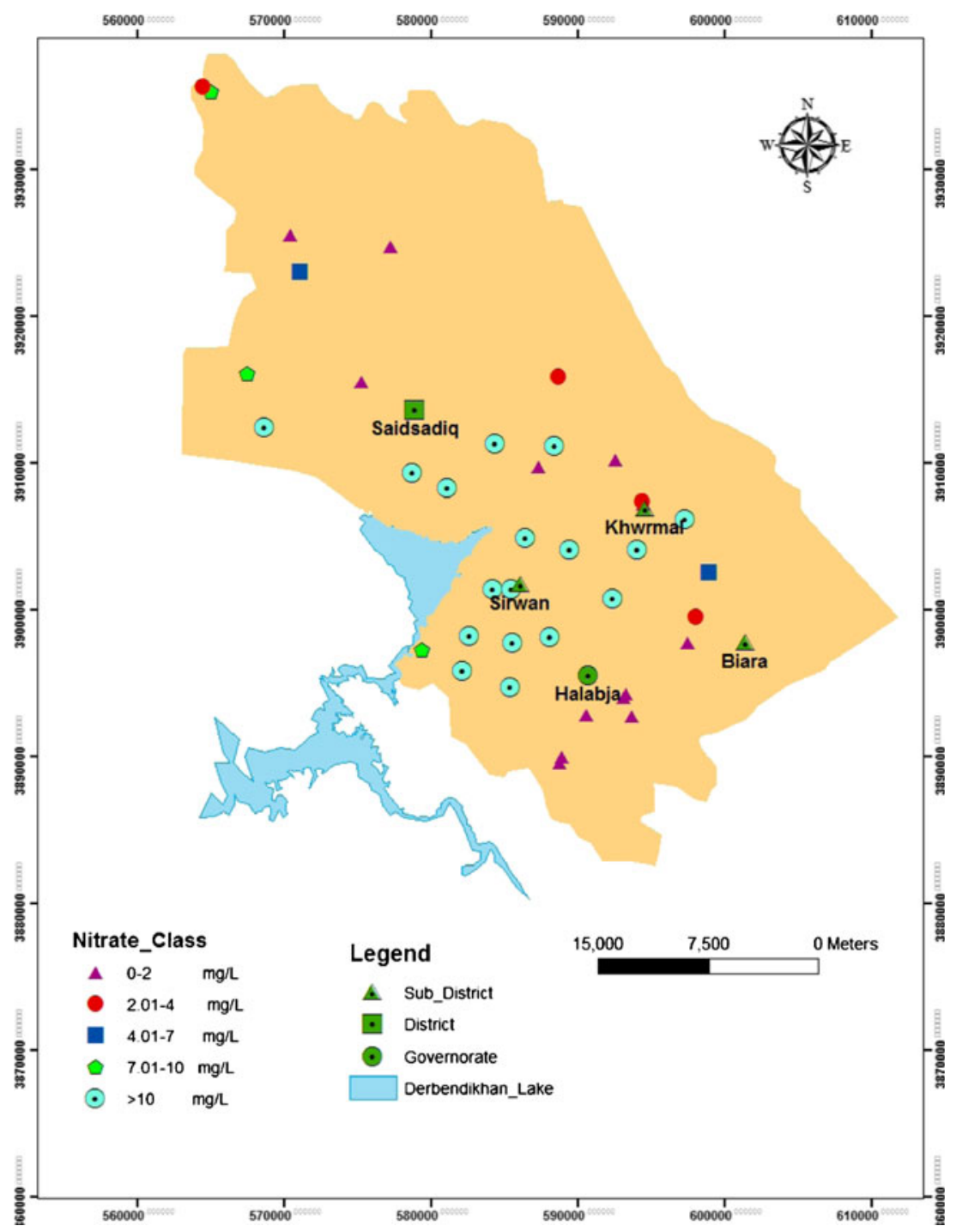

a sensitivity analysis. Equation (7) was used to calculate the effective weight of each parameter (Javadi et al. 2011).

$W=\left(\frac{\mathrm{PrPw}}{\mathrm{V}}\right) \times 100$

where $W$ is the effective weight of each parameter, Pr is the rating value and $\mathrm{Pw}$ is the weight value of each parameter, and $V$ is the overall vulnerability index.

\section{Result and discussion}

\section{Assessment of standard and modified vulnerability mapping}

Figure 7 shows the original vulnerability map of the studied basin with four zones of vulnerability index. These are very low, low, moderate, and high vulnerability index. The map obviously illustrates the dominance of moderate and very low vulnerability zones which covers an area of 614 and $435 \mathrm{~km}^{2}$ or 48 and $34 \%$ of the whole studied area, respectively. The moderate vulnerability zone occupies two different areas in terms of geological and hydrogeological conditions. The first is the area of mountains surrounding the studied basin which comprises the fissured and karstic aquifer. While the second area comprises the Quaternary deposits surrounding the area of Derbandikhan reservoir in the southwest of the basin, this might be related to the high water table level and high percentage of coarse grain material such as gravel, sand, and rock fragment. Furthermore, the zone with low vulnerability comes in the third sequence and occupies $166 \mathrm{~km}^{2}$ or $13 \%$ of the overall surface area of the basin. The zone with a high vulnerability index covers only $64 \mathrm{~km}^{2}$ or $5 \%$ of the total area and is located in the center of basin. This area is characterized by a high water table level and the presence of several springs with fractured limestone. 
Fig. 7 Standard DRASTIC map for study basin

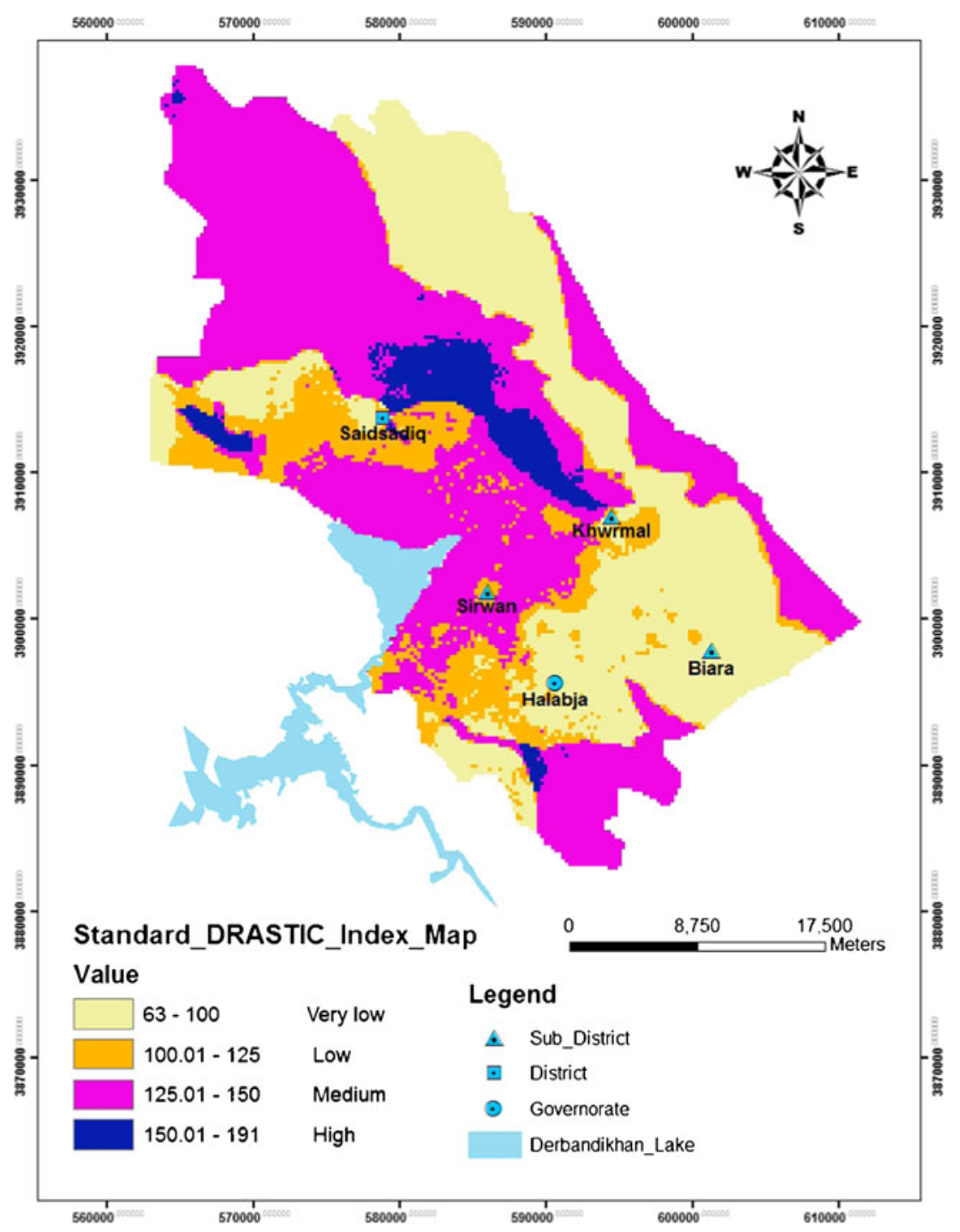

The Pearson's correlation coefficient applied (McCallister 2015) to calculate the relation between standard DRASTIC index value and nitrate concentration, this correlation factor refers to linear correlation between two variables. The outcome was $43 \%$ that is fairly low (Table 4). This means that the intrinsic vulnerability index requires to be modified to illustrate a realistic evaluation of the contamination potential in the studied basin. Therefore, nitrate concentration from 39 sampled points was used on the five maps of standard DRASTIC method separately including DRASTIC maps. The nitrate concentration value and DRSIC rate at each map were measured and then the mean of nitrate value calculated at each range of rate. Based on the Wilcoxon rank-sum non-parametric statistical test, the modified rate of DRSIC parameters were defined. Table 4 shows the modified rate of DRSIC layers based on the nitrate concentration.
Figure 8 exemplifies the new modified DRASTIC map depending on the new rating. It shows that 15 and $29 \%$ of the area fall in the moderate and very low vulnerability zone, respectively. These percentages were 48 and $34 \%$, respectively, before the modification. The calculated area was $15 \%$ for low and $38 \%$ for high vulnerability class while before the modification, it was 13 and $5 \%$, respectively. In addition, a very high vulnerability zone was recognized that covers $3 \%$ of the study basin. To show the spatial distribution of the index before and after the modification, the two maps were compared. The result showed that $15 \%$ had similar classes, while $85 \%$ showed a difference of one class or more, indicating the effectiveness of the proposed method. The result of Pearson's correlation coefficient confirms this effectiveness because rate modified DRASTIC map is $69 \%$ which is significantly higher than the standard one which is equal to $43 \%$. 
Table 4 Standard and modified rates depending on nitrate concentrations

\begin{tabular}{|c|c|c|c|c|}
\hline Parameters & Range & $\begin{array}{l}\text { Standard } \\
\text { rating }\end{array}$ & $\begin{array}{l}\text { Mean nitrate } \\
\text { concentration } \\
(\mathrm{mg} / \mathrm{L})\end{array}$ & $\begin{array}{l}\text { Modified } \\
\text { rating }\end{array}$ \\
\hline \multirow[t]{10}{*}{ Depth to water table } & $0-1.5$ & 10 & 31 & 10.0 \\
\hline & $1.5-4.5$ & 9 & 27.6 & 9.0 \\
\hline & $4.5-7.5$ & 8 & 11.2 & 8.0 \\
\hline & $7.5-10$ & 7 & 10 & 7.0 \\
\hline & $10-12.5$ & 6 & No data & 6.0 \\
\hline & $12.5-15$ & 5 & No data & 5.0 \\
\hline & $15-19$ & 4 & 7.5 & 4.0 \\
\hline & $19-23$ & 3 & 5.83 & 3.0 \\
\hline & $23-30$ & 2 & No data & 2.0 \\
\hline & $>30$ & 1 & 1.45 & 1.0 \\
\hline \multirow[t]{5}{*}{ Net recharge } & $<50$ & 1 & No data & 1.0 \\
\hline & $50-100$ & 3 & 1.6 & 4.0 \\
\hline & $100-175$ & 6 & 1.8 & 6.0 \\
\hline & $175-250$ & 8 & 18.5 & 9.0 \\
\hline & $>250$ & 9 & No data & 10.0 \\
\hline \multirow[t]{3}{*}{ Soil media } & Clay loam with rock fragment & 4 & 1.6 & 4.0 \\
\hline & Silty loam & 7 & No data & 7.0 \\
\hline & $\begin{array}{l}\text { Sandy loam } \\
\text { Thin or absent }\end{array}$ & 10 & 17.7 & 10.0 \\
\hline \multirow[t]{3}{*}{ Impact of vadose zone } & Sand and gravel with clay & 4 & 1.3 & 4.9 \\
\hline & $\begin{array}{l}\text { Limestone with bedded } \\
\text { claystone }\end{array}$ & 5 & 2 & 7.5 \\
\hline & Limestone & 8 & 18.5 & 10.0 \\
\hline \multirow{2}{*}{$\begin{array}{l}\text { Hydraulic } \\
\text { Conductivity }\end{array}$} & $0-4$ & 1 & 1.6 & 1.0 \\
\hline & $12-30$ & 4 & 16.55 & 10.0 \\
\hline
\end{tabular}

\section{Assessment of vulnerability based on sensitivity analysis}

New effective weighting factors were obtained using the standard DRASTIC map and then sensitivity analysis was applied. The mean of effective weight calculated based on the previously explained formula number (Eq. (7)) and are presented in Table 5. Obviously, it can be noticed that there are some significant differences from the theoretical values proposed by Aller et al. (1987) as all parameters changed in its weighting value because the new weighting values calculated are based on the vulnerability index achieved from the specific properties of the ground in the study area while the recommended theoretical values are assumed everywhere in the world. Hydraulic conductivity designates the maximum deviation between the original and new effective weights with $53 \%$ decrease while soil media shows the highest increasing percent which is $31 \%$. The net recharge also decreased in its weight value with only $6 \%$. Moreover, several parameters illustrated an increase in the effective weight value including depth to water, aquifer media, topography, and impact of the vadose zone with increasing percentage of $3,12,3$, and $12 \%$, respectively. Figure 9 shows the weight-modified DRASTIC map using the computed effective weights. The results are slightly different compared to the standard DRASTIC vulnerability map with four classes of vulnerability. These classes are very low, low, moderate, and high with $32,16,38$, and $14 \%$ of the total area, respectively. Because of computed modified vulnerability index based on the specific ground conditions of studied basin, it makes these differences and the modified one more reliable.

\section{Combination of rate and weight modification}

The rates and weights of the variables used were modified as explained in sub-sections "Using nitrate concentration" and "Using sensitivity analysis" using both nitrate concentration and sensitivity analysis methods. The modified rate and weight applied to the DRASTIC model to see the intrinsic vulnerability situation in the area. Both modified rate-weight results have been applied together as well in the same proposed formula in Eq. (2). Figure 10 illustrates the modified rate-weight applied to the DRASTIC model. The outcome 
Fig. 8 Rate modified DRASTIC map using nitrate concentration

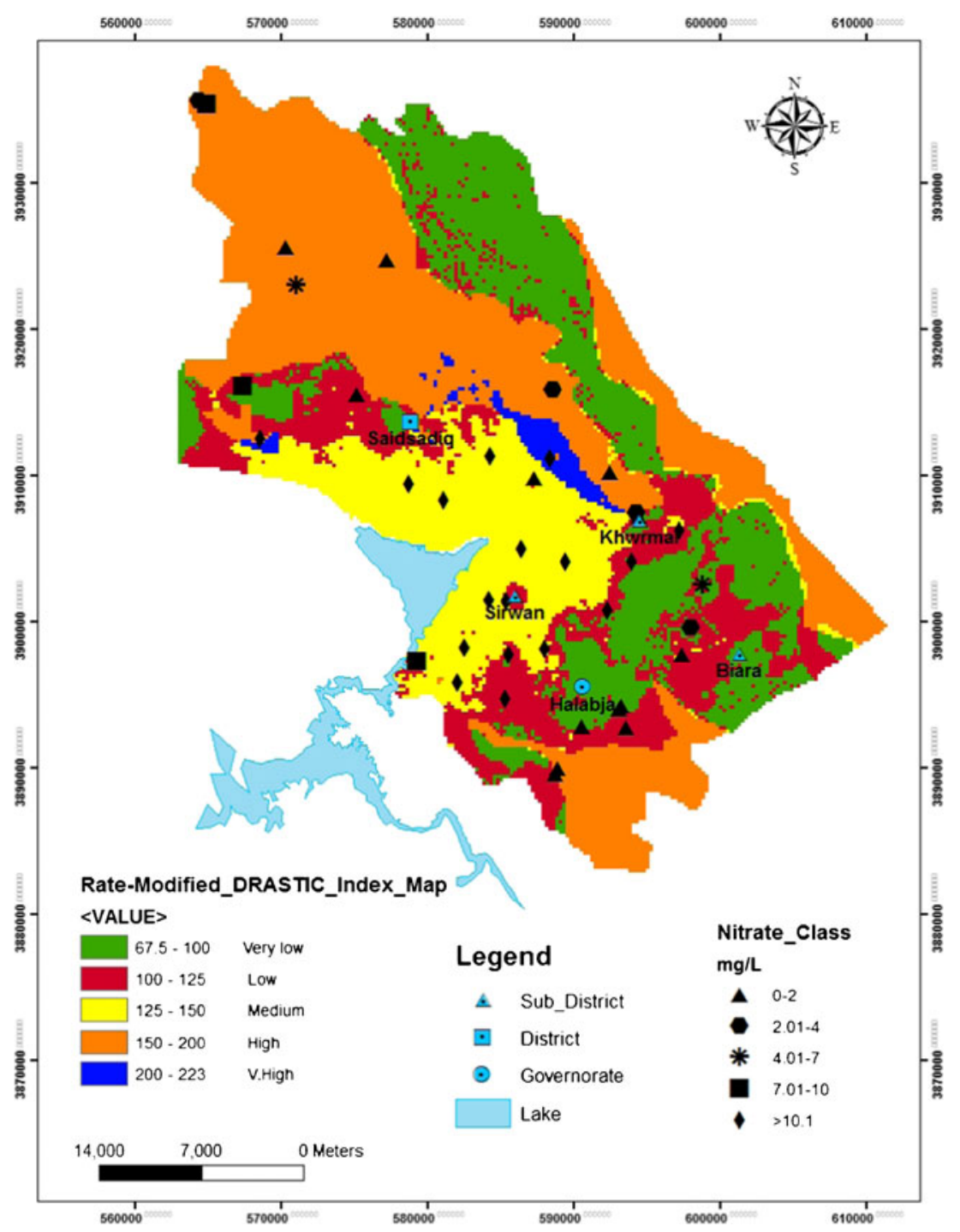

map has great dissimilarity with the standard DRASTIC map and fairly similar to the rate modified using nitrate concentration with some differences in the rate of the low and very low vulnerability zone.

\section{Comparison of modified methods}

\section{Pearson's correlation factor}

Pearson's correlation factor was calculated statistically between the modified DRASTIC index value for all suggested types of modified methods and mean of nitrate concentration. The result tabulated in Table 6 shows an increase in the correlation factor up to $72 \%$. According to these results, the combination of modified rate and weight method has a higher correlation factor and is recommended as the most appropriate method to be applied in the study basin.
Dry-wet seasons variation in nitrate

Every vulnerability map should be validated after construction in order to estimate the validity of the theoretical sympathetic of current hydrogeological conditions (Perrin et al. 2004 cited in Abdullah et al. 2015a). Several methods can be applied for the validation of vulnerability assessments (Zwahlen 2004); these include hydrographs, chemographs, and tracers (natural or artificial). In order to validate both applied models at Halabja Saidsadiq Basin (HSB), nitrate concentration analysis has been selected. Nitrate as a pollution indicator can be helpful to recognize the evolution and changes of groundwater quality. In the particular studied case, the nitrate differences between two following seasons (dry and wet) were analyzed from (39) groundwater samples. The samples were collected and analyzed at the end of September 2014 for dry season and end of May 2015 for wet season. The selected wells for nitrate 
Table 5 Modified weight for standard DRASTIC based on sensitivity analysis

\begin{tabular}{lllllll}
\hline Parameters & $\begin{array}{l}\text { Standard } \\
\text { weight }\end{array}$ & $\begin{array}{l}\text { Standard } \\
\text { weight (\%) }\end{array}$ & \multicolumn{2}{l}{ Effective weight (\%) } & $\begin{array}{l}\text { Mean } \\
\text { modified } \\
\text { weight }\end{array}$ \\
\cline { 4 - 6 } & 5 & 21.7 & Minimum & Mean & Maximum & 5.2 \\
$R$ & 4 & 17.4 & 8.0 & 22.4 & 25.6 & 3.8 \\
$A$ & 3 & 13.0 & 18.0 & 16.3 & 18.5 & 3.4 \\
$S$ & 2 & 8.7 & 16.0 & 14.7 & 13.8 & 2.6 \\
$T$ & 1 & 4.3 & 2.0 & 4.5 & 5.1 & 1.0 \\
$I$ & 5 & 21.7 & 40.0 & 24.5 & 20.5 & 5.6 \\
$C$ & 3 & 13.0 & 6.0 & 6.1 & 6.2 & 1.4 \\
\hline
\end{tabular}

concentration measurement are located nearly in all vulnerability zones at each model.

In relation to nitrate values for dry season (absence of rainfall for a long period) (Table 7), low nitrate levels were identified with concentration values ranging between 0 and just above $10 \mathrm{mg} / \mathrm{L}$. While for wet season which is characterized by a period of high rainfall, the nitrate concentration extremely rose up in all samples. For achieved standard
Fig. 9 Effective weight (weight modified) DRASTIC map based on sensitivity analysis

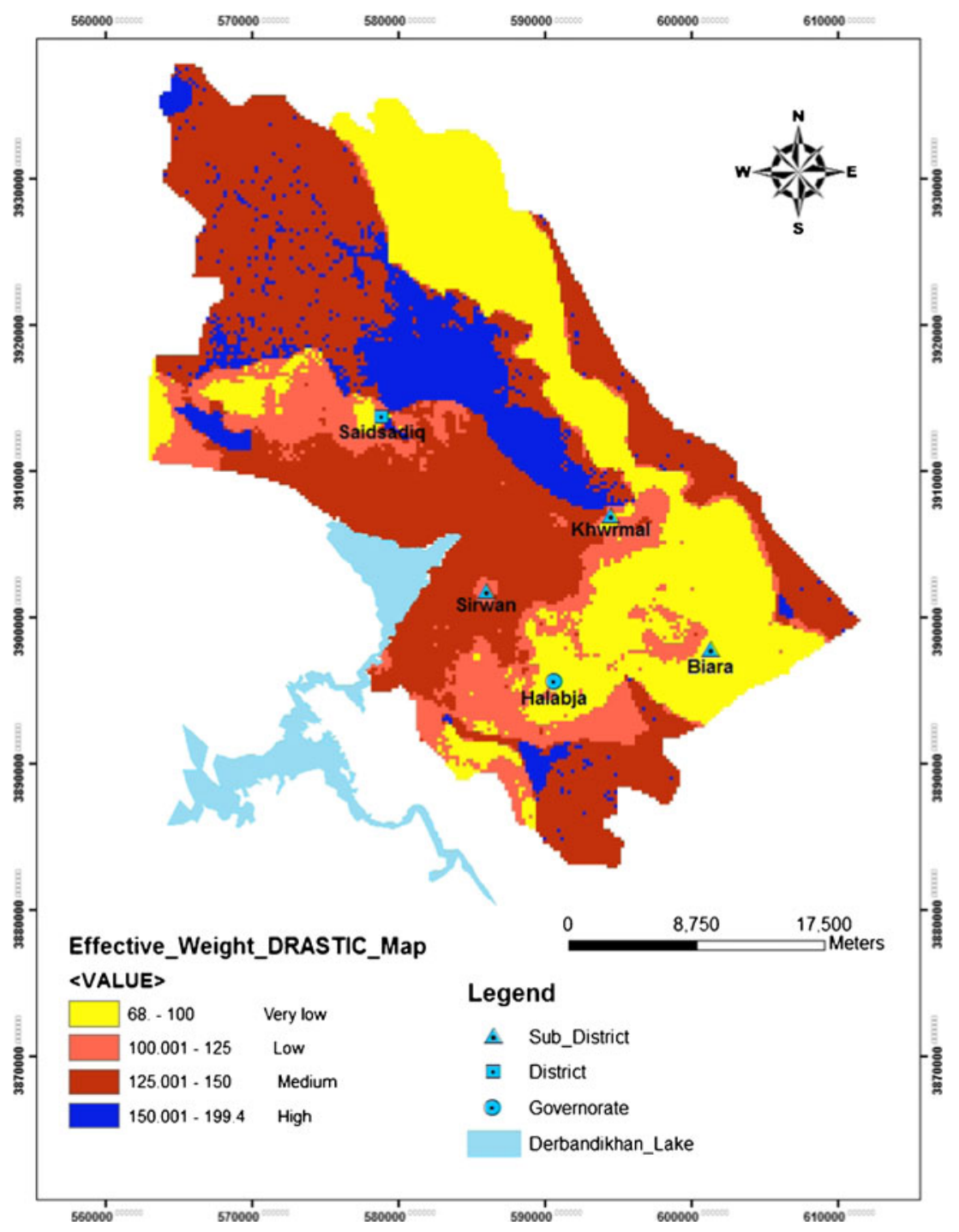


Fig. 10 Combination of rateweight modified of DRASTIC vulnerability map

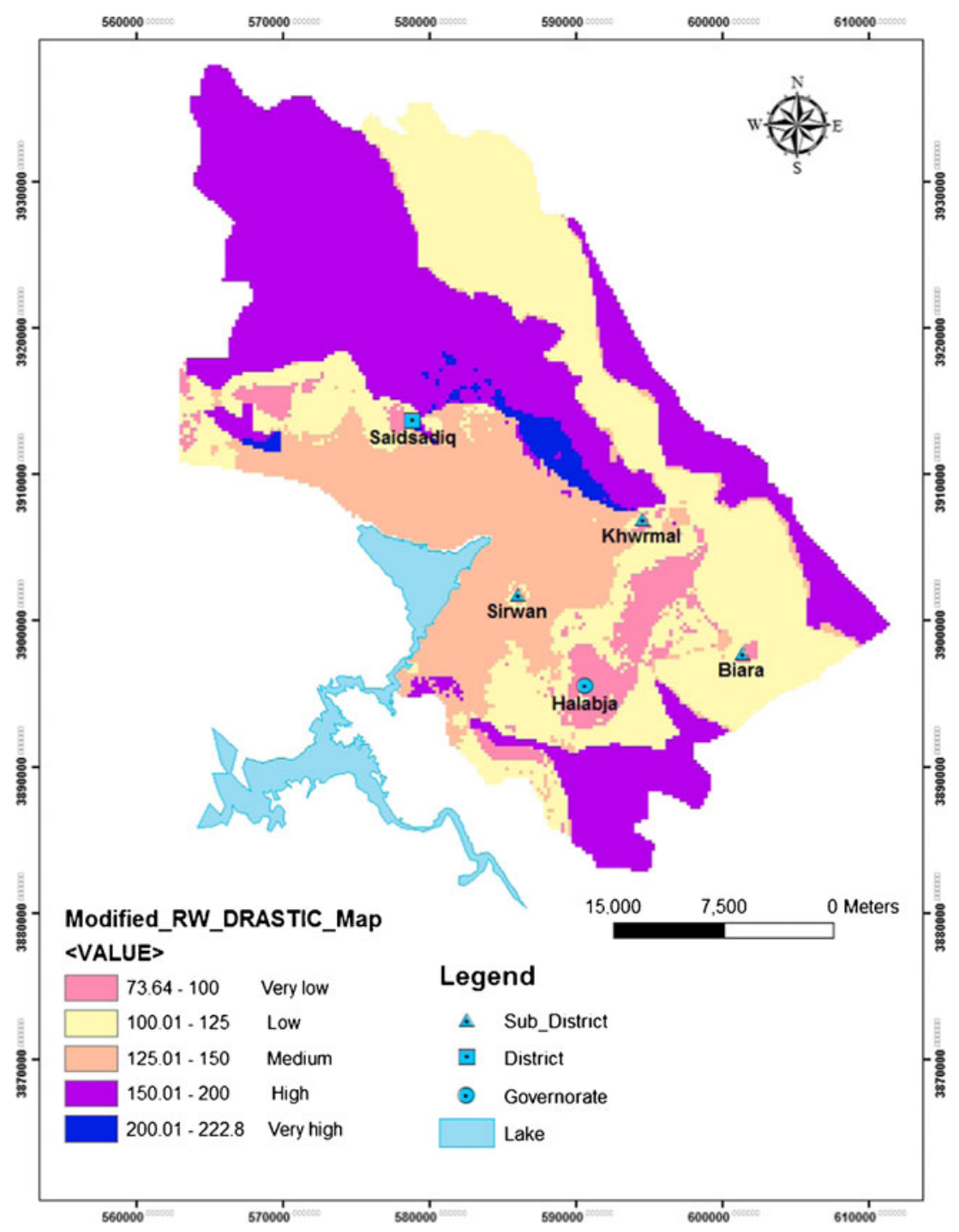

DRASTIC vulnerability classes, namely very low, low, moderate, and high, the averages of nitrate concentration in dry season were $<2,2-4,>10$, and $>10 \mathrm{mg} / \mathrm{L}$, respectively, while in wet season, the concentration significantly rose up (0-20, $20-30,>30$, and $>30 \mathrm{mg} / \mathrm{L}$ ), respectively. This condition refers to several main factors such as rising up the water table in the wet season and vice versa for the dry season. Secondly, the

Table 6 Pearson's correlation factors between the standard and modified vulnerability index and nitrate concentration

\begin{tabular}{lll}
\hline Parameters & $\begin{array}{l}\text { Number } \\
\text { of data }\end{array}$ & $\begin{array}{l}\text { Pearson's } \\
\text { correlation } \\
\text { coefficient (\%) }\end{array}$ \\
\hline Standard DRASTIC index & 39 & 43 \\
Modified weight DRASTIC index & & 57 \\
Modified rate DRASTIC index & 69 \\
Combined modify rate and weight & 72 \\
DRASTIC index & \\
\hline
\end{tabular}

impact of land use activity is significant in wet season specifically using chemical contaminants (nitrate) for agriculture purpose. Finally, rainfall plays an important role to transport nitrate based on specific condition of aquifer characteristics. Consequently, these considerable variations in nitrate concentration from dry to wet seasons verify the suitability of applying this model in HSB.

Furthermore, nitrate concentration again applied in verification for modified DRASTIC model. Vulnerability classes realized by this model in HSB were very low, low, moderate, high, and very high. The low and high classes covered a significant portion of the area of HSB. The average of nitrate concentration in dry season was $>10 \mathrm{mg} / \mathrm{L}$ for both classes. Whereas, for wet season, the concentrations considerably rose up ( $>30 \mathrm{mg} / \mathrm{L})$ for each class. Therefore, these considerable variations in nitrate concentration from dry to wet seasons verify the sensibility of the gradation and distribution of vulnerability levels acquired using the modified DRASTIC model (Fig. 11). 
Table 7 Mean nitrate concentration in both dry and wet seasons at each vulnerability class

\begin{tabular}{|c|c|c|c|c|c|}
\hline \multirow{2}{*}{$\begin{array}{l}\text { Standard DRASTIC } \\
\text { vulnerability category }\end{array}$} & \multicolumn{2}{|c|}{ Mean nitrate concentration $(\mathrm{mg} / \mathrm{L})$} & \multirow{2}{*}{$\begin{array}{l}\text { Rate-weight modified DRASTIC } \\
\text { vulnerability category }\end{array}$} & \multicolumn{2}{|c|}{ Mean nitrate concentration $(\mathrm{mg} / \mathrm{L})$} \\
\hline & Dry season & Wet Season & & Dry season & Wet season \\
\hline Very low & $<2$ & $0-20$ & Very low & $0-2$ & $20-30$ \\
\hline Low & $2-4$ & $20-30$ & Low & $>10$ & $>30$ \\
\hline Medium & $>10$ & $>30$ & Moderate & $>10$ & $>30$ \\
\hline High & $>10$ & $>30$ & High & $>10$ & $>30$ \\
\hline- & - & - & Very high & $>10$ & $>30$ \\
\hline
\end{tabular}

\section{Conclusion}

Both standard and modified DRASTIC index models were applied in GIS environment to assess the potential vulnerability of groundwater contamination in the Halabja Saidsadiq Basin. Seven parameter maps were developed in a GIS environment to generate standard models, and the modification was applied in several phases. Standard DRASTIC method gave acceptable results in the assessment of intrinsic vulnerability of groundwater to pollution, but it is difficult to consider these results as an accurate groundwater vulnerability evaluation. In addition, the results of low Pearson's correlation factor with the nitrate concentration ( $43 \%$ ) proved that standard DRASTIC model needs to be calibrated. Firstly, nitrate concentration applied to modify the original rate proposed by Aller et al. (1987), and secondly, the sensitivity analysis was applied to establish the effective weight of each parameter in DRASTIC model. So both modified rate and weight were applied separately to compute a new DRASTIC model. And then, both modifications applied together to construct the combined rate-weight modified the DRASTIC map. Additionally, the sensitivity weight analysis showed that the $D, A, S$, and $I$ parameters had a considerable impact in the study basin. The proposed modifications might improve the DRASTIC index vulnerability map and groundwater quality management, specifically for the agricultural areas with the use of nitrates. The DRASTIC vulnerability index values ranged between 63-191, 67.5-223, 68-199.4, and 73.64222.8 for the standard, modified rate, modified weight, and

Table 8 Result of DRASTIC index ratio for standard and modified maps

\begin{tabular}{lllll}
\hline $\begin{array}{l}\text { Vulnerability } \\
\text { class }\end{array}$ & $\begin{array}{l}\text { Standard } \\
(\%)\end{array}$ & $\begin{array}{l}\text { Modified } \\
\text { rate }(\%)\end{array}$ & $\begin{array}{l}\text { Modified } \\
\text { weight } \\
(\%)\end{array}$ & $\begin{array}{l}\text { Combined } \\
\text { modification }\end{array}$ \\
\hline Very low & 34 & 29 & 32 & 7 \\
Low & 13 & 15 & 16 & 35 \\
Medium & 48 & 15 & 38 & 19 \\
High & 5 & 38 & 14 & 35 \\
Very high & - & 3 & - & 4 \\
\hline
\end{tabular}

combined modification, respectively, and the percentage rate of each class is explained in the Table 8.

Pearson's correlation factor showed that there is a good relation between the modified DRASTIC index and nitrate concentration which were 69,57 , and $72 \%$ for modified (rate (using nitrate), weight (sensitivity analysis), and combined rate-weight methods, respectively. The factor value of all types of modifications was higher than the standard one which is $(43 \%)$. On the other hand, the considerable variations in nitrate concentration from dry to wet seasons verify the sensibility of the gradation and distribution of vulnerability levels acquired using the modified DRASTIC model (Fig. 11). So these two factors confirmed that the combined rate-weight modification is the most appropriate method to apply in the studied basin.

Nitrate concentration classified the area into five classes $(0-2,2.01-4,4.01-7,7.01-10$, and more than $10 \mathrm{mg} / \mathrm{L})$. The very high, high, and moderate vulnerable zones were characterized by a high percentage of nitrate concentration as they are situated in more than $10 \mathrm{mg} / \mathrm{L}$ class, this is definitely related to extensive agriculture activity and closeness to the wastewater discharges as well, while zones of very low and low situated in classes of 0-2 and 2-4, respectively. Apart from the mountain area which utility of nitrate is impossible so the nitrate analysis samples had not been collected and the same standard rate value was used. Finally, the results confirmed that the modified DRASTIC was significantly more sensible than the standard method.

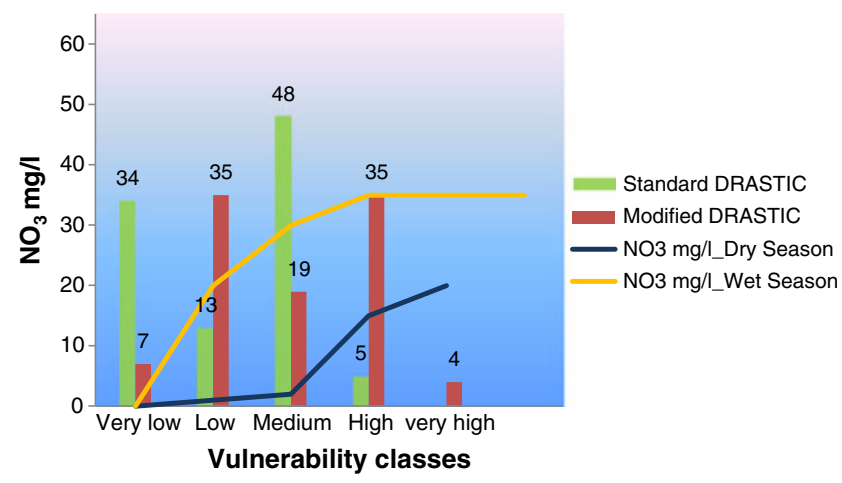

Fig. 11 Comparison of both models with mean nitrate concentration 
Open Access This article is distributed under the terms of the Creative Commons Attribution 4.0 International License (http:// creativecommons.org/licenses/by/4.0/), which permits unrestricted use, distribution, and reproduction in any medium, provided you give appropriate credit to the original author(s) and the source, provide a link to the Creative Commons license, and indicate if changes were made.

\section{References}

Abdullah TO, Ali SS, Al-Ansari NA and Knutsson S (2015a). Effect of agricultural activities on groundwater vulnerability: case study of Halabja Saidsadiq Basin, Iraq. J Environ Hydrol 23(10). The open access electronic journal found at http://www.hydroweb.com/ protect/pubs/jeh/jeh2015/AnsariGW.pdf

Abdullah TO, Ali SS, Al-Ansari NA, Knutsson S (2015b) Groundwater vulnerability mapping using lineament density on standard DRASTIC model: case study in Halabja Saidsadiq Basin, Kurdistan Region, Iraq. Engineering 7:644-667. doi:10.4236/eng. 2015.710057

Ali SS (2007) Unpublished PhD thesis, Faculty of Mining and Geology. In: Geology and hydrogeology of Sharazoor-Piramagroon basin in Sulaimani area, northeastern Iraq. University of Belgrade, Serbia, p. 317

Allen RG, Pereira L S, Raes D, and Smith M (2006) Crop evapotranspiration, guidelines for computing crop water requirements-FAO Irrigation and drainage paper No. 56, P.23

Aller L, Bennett T, Lehr JH, Petty RH, Hackett G (1987) USEPA report 600/2-87/035. In: Kerr RS (ed) DRASTIC: a standardized system for evaluating groundwater pollution potential using hydrogeologic setting, vol 74820. Environmental Research Laboratory, Ada, Oklahoma, p. 252

Babiker IS, et al. (2005). A GIS-based DRASTIC model for assessing aquifer vulnerability in Kakamigahara Heights, Gifu Prefecture, central Japan. Sci Total Environ, 345 (1-3), 127-140

Baziany MMQ (2006) Kurdistan region, Msc thesis. In: Stratigraphy and sedimentology of former Qulqula Conglomerate Formation. Sulaimani University, NE-Iraq, 98p

Baziany MMQ, Karim KH (2007) A new concept for the origin of accumulated conglomerates, previously known as Qulqula Conglomerate Formation at Avroman-Halabja area, NE-Iraq. Iraqi Bull Geol Mining 3(2):33-41

Bellen RC, Dunnington HV, Wetzel R, and Morton D. (1959). Lexique Stratigraphique International. Asie, Iraq. Vol. 3C, 10a, 333

Berding F (2003) Agro-ecological zoning of the three northern governorates of Iraq. FAO Agricultural Rehabilitation Programme. Plant production SS, Erbil, Iraq

Buday T (1980) Regional Geology of Iraq. Stratigraphy, I.I. Kassab and SZ Jassim (Eds) D. G. Geo Survey. Min. Invest. Publication. Vol. 1, 445

Buday T, and Jassim S (1987) The regional geology of Iraq: tectonics, magmatism, and metamorphism. I.I. Kassab and M.J. Abbas (Eds), Baghdad, $445 \mathrm{p}$

FAO (2001) Representation in Iraq. Reconnaissance soil map of the three northern governorates, Iraq. Map Scale $=1: 1000,000$. Erbil SubOffice

Fritch TG, McKnight CL, Yelderman Jr, J C, and Arnold JG (2000) An aquifer vulnerability assessment of the paluxy aquifer, central Texas, USA, using GIS and a modified DRASTIC approach. Environ Manag, 25, 337-345
GWDS (2014) Groundwater Directorate in Sulaimaniyah. Archive department

Hamamin D F (2011) Hydrogeological assessment and groundwater vulnerability map of Basara Basin, Sulaimani Governorate, Iraq, Kurdistan Region. Unpublished PhD thesis, College of Science, University of Sulaimani. 174P

Hernandez L R, Bravo J A and Mejuo M F (2004) Map of vulnerability to groundwater contamination. Excelentisima Diputacion Provincial de Alicante, Espana. A-1029-2004. Cited in Hamamin D.F. (2011). Hydrogeological assessment and groundwater vulnerability map of Basara Basin, Sulaimani Governorate, Iraq, Kurdistan Region. Unpublished $\mathrm{PhD}$ thesis, College of Science, University of Sulaimani. 174P

Huang T, Pang Z, Edmunds W (2012) Soil profile evolution following land-use change: implications for groundwater quantity and quality. Hydrol Process 27(8):1238-1252

Jassim SZ and Guff JC (2006) Geology of Iraq. Jassim (Eds) D. G. Geo Survey Min Invest Publication. 340p

Javadi S, Kavehkar N, Mohammadi K, Khodadi A, Kahawita K (2011) Calibration DRASTIC using field measurement, sensitivity analysis and statistical method to assess groundwater vulnerability. Water International 36(6):P719-32

Kalinski RJ et al. (1994) Correlation between DRASTIC vulnerabilities and incidents of VOC contamination of municipal wells in Nebraska. Ground Water 32(1):31-34

Lee S (2003) Evaluation of waste disposal site using the DRASTIC system in southern Korea. Environ Geol 44: 654-664

McCallister J, 2015 Pearson correlation coefficient: formula, example \& significance. Available at: http://study.com/academy/lesson/ pearson-correlation-coefficient-formula-example-significance.html last accessed 17th March, 2015

Mehta VK, Walter MT, and DeGloria D S (2006) A simple water balance model. Cornell University, technical report No.5, 9p

Neshat A, Pradhan B, Pirasteh S and Shafri H (2013) Estimating groundwater vulnerability to pollution using a modified DRASTIC model in the Kerman agricultural area,Iran Environ Earth Sci P1-13

Neshat A, Pradhan B, Dadras M (2014) Groundwater vulnerability assessment using an improved DRASTIC model in GIS. Resour Conserv Recycl 86:74-86

Panagopoulos G, Antonakos A, Lambrakis N (2006) Optimization of the DRASTIC method for groundwater vulnerability assessment via the use of simple statistical methods and GIS. Hydrogeol J 14:894-911

Perrin J, Pochon A, Jeannin PY, Zwahlen F (2004) Vulnerability assessment in karstic areas: validation by field experiments. Environ Geol $46,237-245$

Piscopo G (2001) Groundwater vulnerability map, explanatory notes, Castlereagh Catchment, NSW. Department of Land and Water Conservation, Australia, Found at: http://www.dlwc.nsw.gov.au/ care/water/groundwater/reports/pdfs/castlereagh_map_notes.pdf

Plymale CL and Angle MP (2002) Groundwater pollution potential of Fulton County, Ohio. Groundwater pollution potential, report 45. Columbus, OH: Ohio Department of Natural Resources Division of Water, Water Resources Section

Statistical Directorate in Sulaimaniyah (2014) Archive Department

Wilcoxon F (1945) Individual comparison by ranking method, Biom Bull $1,6,80-83$

Zwahlen F (ed) (2004) Vulnerability and risk mapping for the protection of carbonate (karst) aquifers, final report (COST action 620). European Commission, Brussels 